\title{
1. Introduction to the Research Handbook on Intellectual Property and Technology Transfer
}

Jacob H Rooksby

University researchers help improve lives by solving problems that impact health, happiness, and societal wellbeing. Universities harness the power of faculty innovations and disseminate them to the public, using intellectual property to create protections and provide rewards. This process of technology transfer has been vibrant in US universities since at least the Second World War and has grown in importance everywhere since then. The Bayh-Dole Act of 1980 helped spark formalized attention to technology transfer in the US and has inspired similar legislation in countries across the globe.

Nearly forty years since the beginning of concerted attention to the topic, technology transfer has come of age. Institutions have grown in their sophistication and enhanced their abilities to be of service to society through innovation. Indeed, institutional governing boards and the public increasingly demand it. A focus on innovation and economic development figures prominently in institutional mission statements and the day-in, day-out functioning of the university. Entrepreneurial spirits are not uncommon, and faculty frequently think in terms of the value of their research and the potential contributions it can make to humankind.

At the same time that higher education has adopted market-based approaches and incentives for the commercialization of technology, universities face ever more legal complexities and challenges. Changes to the patent law in the US in 2011 have led to a landscape where the stakes are higher, and the costs are greater, than ever before for universities seeking success in this realm. While universities face pressures to keep up, they also face criticism from all quarters: both that they are insufficiently savvy in the business and legal markets, and insufficiently sensitive to the ramifications of their participation in those markets. The public interest in reaping the benefit of university research reigns supreme, but the vexing question still remains of how universities can best further the public interest through their approaches to intellectual property and technology transfer.

Through twenty-one chapters, this book speaks to the past and present of technology transfer and intellectual property. Part I examines the policies, practices, and politics that led to the current system of technology transfer and intellectual property management on academic campuses. Both established and emerging authors provide perspective on important topics such as institutional intellectual property policies and technology transfer structures; the politics of technology transfer; the enduring legacy and influence of the Bayh-Dole Act; organizational design and technology transfer; policy advocacy and organizational change at the Association of University Technology Managers; conflicts of interest and conflicts of interest policies; and intellectual property valuation in the academic technology transfer setting.

Part II examines technology transfer and intellectual property in what I call the "innovative university," as it now exists or soon will. The innovative university is at the frontier of knowledge production and dissemination. Its raison d'être is innovation. Functioning less like a bureaucracy, and more like a market-situated, public-oriented research enterprise, 


\section{Research handbook on intellectual property and technology transfer}

the innovative university mixes public and private resources and approaches in its efforts to further its mission. Intellectual property protections serve both as a source of opportunity and anxiety for universities attempting to achieve technology transfer in a complex, expensive, and highly-regulated innovation marketplace. Chapters in Part II consider such topics as the innovation arms race in higher education; tacit knowledge and university-industry technology transfer; technology transfer and the public good; patent sales by US universities; intellectual property exchanges and auctions; university involvement in patent litigation and the complexities of patent enforcement; university participation in inter partes review; data governance; and open science in the age of personal data protection.

Part III concludes the book by offering global perspectives on many of these topics. Authors in that part contribute important information on intellectual property and technology transfer in Europe and China, as well as the treatment of 3D printing in higher education in a selection of countries.

I hope you enjoy reflecting on chapters in this book as we collectively consider the promise of technology transfer and intellectual property to further the common good worldwide in the 21 st Century. 